ks. Stanisław Wronka

\title{
Transliteracja i transkrypcja alfabetu hebrajskiego
}

Pisanie czcionką hebrajską w dobie komputerów jest technicznie bardzo ułatwione, ale wciąż używa się zapisu słów hebrajskich przy pomocy alfabetu łacińskiego, i to zarówno w publikacjach popularnonaukowych, jak i w pracach ściśle naukowych. Panuje przy tym duża różnorodność stosowanych systemów zapisu, tak że w praktyce trudno spotkać dwóch autorów, nawet tej samej narodowości, którzy oddawaliby wyrazy hebrajskie w identyczny sposób. A niekiedy bywa i tak, że ten sam autor stosuje różny zapis w obrębie jednego dzieła. Taki stan rzeczy bierze się zapewne często $\mathrm{z}$ niedopatrzenia wydawcy lub z trudności typograficznych w uwzględnianiu wszystkich znaków diakrytycznych, ale jest też po części spowodowany tym, że zapisywanie tekstu hebrajskiego alfabetem łacińskim nie jest rzeczą prostą.

Dlatego chcielibyśmy przedstawić pewien system, wybierając konkretne rozwiązania spośród wielu istniejących i używanych zapisów, i wyjaśnić go $^{1}$. Być może propozycja ta mogłaby stać się przedmiotem dyskusji, aby dojść do pewnych uzgodnień. To prawda bowiem, że varietas delectat, ale w tym wypadku jednolitość i precyzja byłyby chyba bardziej pożądane, zwłaszcza przez nieznających lepiej języka hebrajskiego, choć zapewne nie tylko przez nich.

\section{Transliteracja a transkrypcja}

Najpierw jednak konieczne jest rozróżnienie pomiędzy transliteracją a transkrypcją, którego na ogół się nie dostrzega, używając dwóch terminów

${ }^{1}$ Istnieje ogromna rozpiętość wśród systemów zapisywania tekstu hebrajskiego alfabetem łacińskim, od maksymalistycznych starających się oddać każdy graficzny znak hebrajski po minimalistyczne inspirujące się przeważnie współczesną wymową hebrajską. Naukowcy próbują znaleźć kompromis pomiędzy tymi dwoma tendencjami, co nie jest jednak łatwe; por. P. Joüon, T. Muraoka, A Grammar of Biblical Hebrew, tłum. z francuskiego, t. 1, Roma 1991 (1996), s. 35-36 (Subsidia Biblica, 14.1). Nasza propozycja skłania się ku rozwiązaniom maksymalistycznym, chociaż podamy też przykłady uproszczonej transliteracji i transkrypcji. 
zamiennie. Tymczasem językoznawcy zwracają uwagę na różnice pomiędzy tymi dwoma pojęciami.

„Przez transliterację rozumiemy taką konwersję pisma, która polega na oddawaniu liter jednego alfabetu za pomocą liter innego alfabetu (w razie potrzeby zaopatrzonych w nietypowe znaki diakrytyczne) bez uwzględnienia fonetycznych właściwości głosek oznaczanych przez litery w alfabecie transliterowanym.

Przez transkrypcję natomiast rozumiemy taką konwersję pisma, która polega na oddawaniu fonetycznym właściwości głosek oznaczanych literami jednego alfabetu za pomocą systemu ortograficznego innego alfabetu.

Różnica między transliteracją i transkrypcją jest więc dość istotna: w transliteracji chodzi jedynie o konsekwentne oddawanie liter jednego alfabetu za pomocą liter innego alfabetu, w transkrypcji natomiast - o oddawanie brzmienia poszczególnych głosek.

Inny jest również zakres zastosowania transliteracji, a inny - transkrypcji. System transliteracji stosujemy w pracach ściśle naukowych, w językoznawstwie oraz przy sporządzaniu opisów katalogowych i bibliograficznych w bibliotekach naukowych; system transkrypcji - we wszystkich wydawnictwach popularnych, popularnonaukowych i artystycznych oraz we wszystkich bibliotekach szkolnych, i powszechnych"2.

\section{System transliteracji i transkrypcji}

Zobaczmy teraz tabelę proponowanego systemu transliteracji i transkrypcji, najpierw spółgłosek hebrajskich, a potem znaków samogłoskowych.

SPÓŁGŁOSKI

\begin{tabular}{|c|c|c|c|c|}
\hline Litera & Nazwa & Transliteracja & Transkrypcja & Wartość liczbowa \\
\hline א & 'álè & , & - & 1 \\
\hline$\supseteq 2$ & bêt & $b, \underline{b}$ & $b, w$ & 2 \\
\hline 22 & gî́mel & $g, \bar{g}$ & $g$ & 3 \\
\hline ד ד & dáleț & $d, \underline{d}$ & $d$ & 4 \\
\hline ה & $h \bar{e}$ & $h$ & $h$ & 5 \\
\hline 1 & $w \bar{a} w$ & $w$ & $w$ & 6 \\
\hline$i$ & zájin & $z$ & $z$ & 7 \\
\hline$\pi$ & $h \bar{e} \underline{t}$ & $h$ & $c h$ & 8 \\
\hline ט & $t \bar{e} \underline{t}$ & $t$ & $t$ & 9 \\
\hline , & jōd & $j$ & $j$ & 10 \\
\hline
\end{tabular}

${ }^{2}$ Stownik ortograficzny języka polskiego wraz zzasadami pisowni i interpunkcji, red. M. SzYMCZAK, Warszawa 1976, s. 140; por. S. SIEROTwIŃSKI, Słownik terminów literackich, Kraków ${ }^{5} 1994$, s. 269; Transliteracja alfabetu hebrajskiego, Wydawnictwa Normalizacyjne 1975, s. 1-2. 


\begin{tabular}{|c|c|c|c|c|}
\hline$\Xi \supset$ & $k \bar{a} \bar{p}$ & $k, \underline{k}$ & $k, c h$ & $20,500^{3}$ \\
\hline ל & lámed & $l$ & $l$ & 30 \\
\hline ם מ & $m \bar{e} m$ & $m$ & $m$ & 40,600 \\
\hline נ & nûn & $n$ & $n$ & 50,700 \\
\hline 0 & sámek & $s$ & $s$ & 60 \\
\hline ע & 'ájin & ‘ & - & 70 \\
\hline$\Xi 9$ & $p \bar{e}(h)$ & $p, \bar{p}$ & $p, f$ & 80,800 \\
\hline$\ddot{\gamma}$ & $s \bar{a} d \underline{e}(h)$ & $s$ & $c$ & 90,900 \\
\hline$p$ & $q \bar{o} \bar{p}$ & $q$ & $q$ & 100 \\
\hline 7 & $r \bar{e} \bar{s}$ & $r$ & $r$ & 200 \\
\hline ש & sîn & $\dot{s}$ & $s$ & 300 \\
\hline שש & šîn & $\check{S}$ & $s z$ & , \\
\hline ת ת & $t \bar{a} w$ & $t, \underline{t}$ & $t$ & 400 \\
\hline
\end{tabular}

ZNAKI SAMOGEOSKOWE

\begin{tabular}{|c|c|c|c|}
\hline Znak & Nazwa znaku & Transliteracja & Transkrypcja \\
\hline 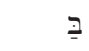 & pátah & $b a$ & $b a$ \\
\hline 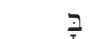 & qúmes & $b \bar{a}$ & $b a$ \\
\hline דבי & (nie na końcu wyrazu) & $b \hat{a}$ & $b a$ \\
\hline בְּה & (tylko na końcu wyrazu) & $b \bar{a}(h)$ & $b a$ \\
\hline$\prod_{-\pi}$ & hātê̄p pátah & $h^{\check{a}}$ & cha \\
\hline$\underline{7}$ & $\begin{array}{l}\text { pátah furtivum } \\
\text { (tylko na końcu wyrazu) }\end{array}$ & ${ }^{a} h$ & ${ }^{a}$ ch (bardzo krótkie) \\
\hline$\frac{7}{\because}$ & $s^{e} \bar{g} \bar{o} l$ & be & be \\
\hline 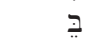 & sērê & $b \bar{e}$ & be \\
\hline בַי & șerề gādôl & bê & be \\
\hline בֶיר & $s^{e} \bar{g} \bar{o} l g \bar{a} d \underline{d o l}$ & bê & be \\
\hline בֶה ה & (tylko na końcu wyrazu) & $b \bar{e}(h)$ & be \\
\hline בֶֶה & (tylko na końcu wyrazu) & $b e(h)$ & be \\
\hline$\stackrel{7}{?}$ & $\check{s}^{e} w \bar{a}$ & $b^{e}, b$ & $b^{e}$ (bardzo krótkie), $b$ \\
\hline$\pi$ & hātēep $s^{e} \bar{g} \bar{o} l$ & $h^{\check{e}}$ & che \\
\hline$\stackrel{7}{T}$ & qáames hạatûp & bo & bo \\
\hline ב & hốlem & $b \bar{o}$ & bo \\
\hline בוּוֹ & hốlem gādôl (wāw hốlem) & bô & bo \\
\hline בוה & (tylko na końcu wyrazu) & $b \bar{o}(h)$ & bo \\
\hline$\prod_{\mathrm{T}}$ & hàtê̄p quámes & $h^{\check{o}}$ & cho \\
\hline$\dddot{7}$ & hî́req & $b i$ & $b i$ \\
\hline בִּי & hî́req gādôl & $b \hat{\imath}$ & $b i$ \\
\hline 7 & qibbûs & $b u$ & $b u$ \\
\hline בוּו & šúreq & $b \hat{u}$ & $b u$ \\
\hline
\end{tabular}




\section{Objaśnienia spółgłosek}

Brak dagesza (kropka w środku spółgłoski) w grupie BeGaDKeFaT zaznaczamy w transliteracji przez dodanie kreski pod lub nad literą: כָרָת

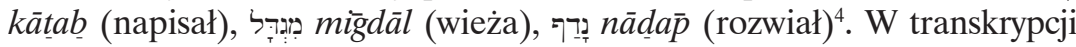
brak dagesza uwidacznia się tylko przy trzech spółgłoskach z tej grupy, które mają wówczas wyraźnie inną wymowę, nie zwarto-wybuchową, lecz szczelinowo-przydechową: $z w, z c h, \Xi f$. Dagesz forte oznaczający podwojenie spółgłoski oddaje się przez powtórzenie danej litery. Występuje on najczęściej w spółgłosce znajdującej się w środku wyrazu: הַפְ hammelek (król), bardzo

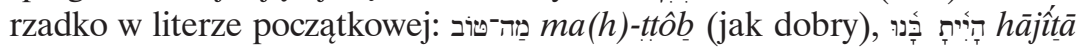
bbấnû (byłeś w nas) ${ }^{5}$, a tylko sporadycznie w literze końcowej: š 'atte (ty, rodz. żeński). W spółgłoskach spoza grupy $\mathrm{BeGaDKeFaT} \mathrm{dagesz} \mathrm{jest} \mathrm{zawsze}$ forte, natomiast we wspomnianej grupie może być także lene, kiedy oznacza tylko zwarto-wybuchową wymowę tych spółgłosek: $b, g, d, k, p, t$. Ma to miejsce prawie zawsze w literze początkowej: בּ̇ bájit (dom), natomiast w środku i na końcu wyrazu tylko wtedy, gdy przed spółgłoską z dageszem stoi $s z^{e} w a$,

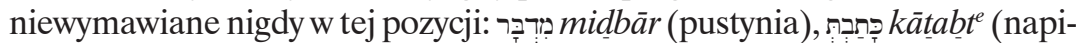
sałaś). W przeciwnym razie, gdy poprzedza ją jakaś samogłoska, spółgłoska

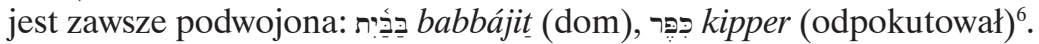

${ }^{3}$ Te setki oznaczane są przez formy końcowe liter: $\rceil$, घ, ๆ, ๆ, ץ; por. J. W. L. RosŁon, Podręcznik języka hebrajskiego. Kurs podstawowy i wyższy, Warszawa 1969, 135; Transliteracja alfabetu hebrajskiego, s. 3-4.

${ }^{4}$ Spółgłoski $g$ i $p$ można też po prostu podkreślić $(g, \underline{p})$ lub postawić kreskę zupełnie pod nimi (g, p), jak to czynią np. G. Deiana, A. Spreafico, S. Bazyliński, Wprowadzenie do hebrajszczyzny biblijnej, tłum. z włoskiego, Warszawa 2001, s. 7. Dawniej, gdy spółgłoski tej grupy nie miały dagesza, dodawano do nich $h: b h, g h, d h, k h, p h$ (lub $f), t h$; por. np. P. Joüon, Grammaire de l'hébreu biblique, Rome 1923 (1965), s. 12. 17; A. CARrozzInI, Grammatica della lingua ebraica, ${ }^{2} 1966$ (1996), s. 1. P. JoüOn, T. MuraOKA, A Grammar of Biblical Hebrew, s. 21. 35 , transliterują $=\operatorname{przez~} h \mathrm{z}$ łukiem u dołu. Inni natomiast oddają tę spółgłoskę przez $x$.

${ }^{5} \mathrm{~W}$ ostatnim przykładzie jest to tzw. dagesz łączący, spowodowany ścisłym związkiem dwóch wyrazów. Stawia się go czasem w początkowej spółgłosce wyrazu, jeśli ma on akcent na pierwszej sylabie i jest poprzedzony wyrazem kończącym się na nieakcentowane $-\bar{a},-\bar{a}(h)$, -e(h) lub wyjątkowo -û; por. P. Joüon, T. Muraoka, A Grammar of Biblical Hebrew, s. 80-82; A. Carrozzini, Grammatica della lingua ebraica, s. 8; T. O. LAmbdin, Introduction to Biblical Hebrew, London 1973 (1980), s. 208.

${ }^{6}$ Pewna dwuznaczność może występować przy $j$ z dageszem poprzedzonym przez $i$ "-. Można bowiem czytać tę zbitkę jako $\hat{\imath}+j$ albo jako ijj. Chyba słuszniejsza jest ta druga

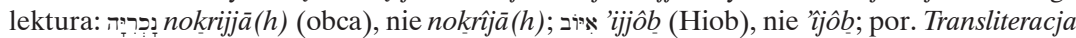
alfabetu hebrajskiego, s. 6; P. JoüOn, T. MuraOKA, A Grammar of Biblical Hebrew, s. 264-265. 267. 269. 271; E. JENNI, Lehrbuch der hebräischen Sprache des Alten Testaments. Neubearbeitung des „Hebräischen Schulbuchs”von Hollenberg-Budde, Zweite, durchgesehene Auflage, Basel-Frankfurt am Main 1981, s. 226; C. JAKUBIEC (opr.), Księga Hioba. Wstęp - przekład z oryginału - komentarz-ekskursy (Pismo Święte Starego Testamentu 7, 1), Poznań-Warszawa 1974, s. 23; T. O. LambDin, Introduction to Biblical Hebrew, s. XXVII. 
Formy końcowe pięciu spółgłosek $(\mathrm{KaMNaFeC})$ oddajemy w transliteracji i transkrypcji identycznie jak ich formy podstawowe: כָּ kallēk, kallech

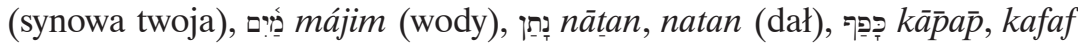
(zgią), צ's ș̂s, cuc (kwitnąć).

Spółgłoski gardłowe $\mathrm{x}$ i ע zaznaczamy w transliteracji jak odpowiednio przydech słaby i mocny w grece (', '), z tym że nie piszemy ich nad samogłoską, lecz samodzielnie: אָדָם 'ād̄ām (człowiek),

Dla odróżnienia spółgłosek gardłowych $\mathrm{\pi}$ i $\pi$, pierwszą transliteruje się przez $h$, a drugą przez $h$ z kropką u dołu $(h)$. W transkrypcji natomiast oznacza się też przez $h$ i wymawia jak nasze $h$, a $\pi$ - przez $c h$ i wymawia mocniej, bardziej gardłowo?

Podobnie, aby odróżnić $\bullet$ od $\curvearrowleft$, pierwszą oznaczamy w transliteracji przez $t \mathrm{z}$ kropką u dołu $(t)$, a drugą przez $t$. Wymowa tych spółgłosek jest prawie identyczna, dlatego w transkrypcji używamy $t$ dla oznaczenia $\bullet$, i л.

Spółgłoskę, transliterujemy i transkrybujemy przez $w$, i wymawiamy jako $w$, nie $t^{8}$. Literę ' oddajemy z kolei przez $j$, gdyż odpowiada ona dość dobrze głosce hebrajskiej'.

Spółgłoskę » oddajemy w transliteracji przez s, natomiast w transkrypcji przez $c$, ponieważ mimo że nie odpowiada ona fonetycznie dokładnie głosce hebrajskiej, to jest najbardziej do niej zbliżona ${ }^{10}$.

${ }^{7} \mathrm{~W}$ języku polskim $h$ i $c h$ wymawia się jednakowo, bezdźwięcznie. Dawniej w niektórych regionach Polski (kresy wschodnie, pogranicze ze Słowacją, Ukrainą i Białorusią) ch wymawiano bezdźwięcznie, a $h$ dźwięcznie; por. Słownik ortograficzny języka polskiego, red. M. Szymczak, s. 28; Z. KLEMENSIEwICZ, Prawidła poprawnej wymowy polskiej, Wrocław-Warszawa-Kraków ${ }^{5} 1967$ (Biblioteczka Towarzystwa Miłośników Języka Polskiego, 10), s. 15; P. BĄK, Gramatyka języka polskiego. Zarys popularny, Warszawa ${ }^{9} 1995$, s. 78 (Biblioteka Miłośników Języka).

${ }^{8}$ Wymowa , jak polskie $t$ jest dziś rzadka, proponuje ją np. M. TomaL, Język hebrajski biblijny, Warszawa 2000, s. 20 (Języki Azji i Afryki), a dawniej czynił to P. Joüon, Grammaire de l'hébreu biblique, s. 12. 30. W publikacjach zachodnich spółgłoska ta bywa najczęściej transliterowana i transkrybowana przez $v$.

${ }^{9}$ Prace w języku angielskim, francuskim i hiszpańskim używają $y$, gdyż $j$ wymawia się w nich inaczej, natomiast w publikacjach niemieckich i włoskich pojawia się $j$, czasem obok y; por. E. JENNI, Lehrbuch der hebräischen Sprache des Alten Testaments, s. 18. 21. 2930; A. Carrozzini, Grammatica della lingua ebraica, s. 1; G. Deiana, A. Spreafico, Guida allo studio dell'ebraico biblico, III Edizione, Roma 1992 (1998), s. 5. Także P. Joüon, Grammaire de l'hébreu biblique, s. 12, wymienia obydwie możliwości.

${ }^{10}$ Ta transkrypcja jest dość powszechna w publikacjach polskich, zarówno dotyczących języka hebrajskiego bibijnego (por. G. Deiana, A. Spreafico, S. BAZYLiński, Wprowadzenie do hebrajszczyzny biblijnej, s. 7; A. KUŚMIREK (przekł. i opr.), Hebrajsko-polski Stary Testament. Księga Rodzaju. Wydanie interlinearne z kodami gramatycznymi, transkrypcją oraz indeksami rdzeni, Warszawa 2000, s. XIV), jak i współczesnego (por. A. KLugman, Nowy stownik polsko-hebrajski hebrajsko polski, Warszawa-Tel Awiw ${ }^{3} 1999$, s. VII; S. Ronen, M. Sobelman, Samouczek języka hebrajskiego, Warszawa-Tel Awiw 2000, s. 9). W publikacjach zachodnich wymowę spółgłoski s opisuje się zwykle przez ts, chociaż i ta zbitka nie jest identyczna z dźwię- 
Spółgłoska $p$ jest transliterowana i transkrybowana przez $q$, a wymawia się ją zawsze jako $k^{11}$.

Znakiem transliteracyjnym dla wjest $s^{12}$, z tymże trzeba pamiętać, iż spółgłoska ta wymawiana jest jako $s$ i tak oddawana w transkrypcji. Natomiast litera $v$ jest oznaczana w transliteracji jako $\check{s}$, a wymawia się ją i transkrybuje jako $s z^{13}$.

Jak widać, transliteracja hebrajskich spółgłosek w tym systemie jest bardzo precyzyjna, każda litera ma swój odpowiednik w języku łacińskim. Natomiast $\mathrm{w}$ transkrypcji pewne znaki są niejednoznaczne: $w$ może wska-

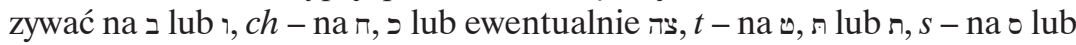
ש, $s z$ - na ש lub ewentualnie io czy

\section{Objaśnienia samogłosek}

Oznaczanie samogłosek hebrajskich jest bardziej skomplikowane. W tabeli przedstawiono wszystkie możliwe warianty kolejno dla samogłosek: $a, e, o, i, u$. Spółgłoski z i п zostały użyte jedynie po to, by pokazać położenie znaków samogłoskowych. Występujące także w tabeli $\pi, \mathrm{l}_{\mathrm{i}}$, nie mają wartości spółgłosek, a więc nie wymawia się ich, lecz są to tzw. matres lectionis, które pomagały pierwotnie odczytać właściwą samogłoskę w tekście spółgłoskowym.

Logika oddawania znaków samogłoskowych jest tu przejrzysta. Samogłoski krótkie są oznaczane prostą literą: $-a,-e,-o,-i,-u$; samogłoski długie - literą z kreską u góry: $-\bar{a},-\bar{e},-\bar{o}$; samogłoski długie z $\mathrm{l}$ lub ' jako

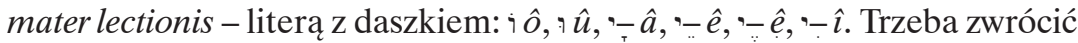
uwagę, że aby oddać różnicę pomiędzy $\cdots \mathrm{i}--$, dla drugiej samogłoski dodaje się pod $\hat{e}$ kropkę $(\hat{e})^{14}$. Samogłoski zredukowane (niektórzy nazywają je półsamogłoskami), czyli $s z^{e} w a$ proste i $s z^{e} w a$ złożone, piszemy w indeksie górnym, aby zaznaczyć, że nie są pełnymi samogłoskami i nie tworzą pełnej

kiem hebrajskim; por. P. JoüOn, Grammaire de l'hébreu biblique, s. 16; P. JoüON, T. MurAOKA, A Grammar of Biblical Hebrew, s. 28; T. O. LAmBdin, Introduction to Biblical Hebrew, s. XVI; E. JENNI, Lehrbuch der hebräischen Sprache des Alten Testaments, s. 28. Można by się zastanowić, czy nie używać $c$ także w transliteracji, która przecież nie musi oddawać dokładnie dźwięku hebrajskiego, jak czyni to A. KUŚMIREK, s. XIV. Niektórzy autorzy niemieccy transliterowaliby s przez $z$, wymawiane podobnie jak nasze $c$, ale litera ta oddaje już $\uparrow$.

${ }^{11}$ Niekiedy jest też transkrybowana przez $k$.

${ }^{12}$ Godna uwagi jest propozycja A. KuŚMIREK (przekł. i opr.), Hebrajsko-polski Stary Testament. Księga Rodzaju, s. XIV, by oddawać tę spółgłoskę przez $\hat{s}$. Litera ta wydaje się odpowiedniejsza od $s$, ponieważ nawiązuje do $\breve{s}$ dla $ש$, a nie kojarzy się z naszym ś. Przeciw przemawia właściwie tylko to, że ś weszło już powszechnie w użycie.

${ }^{13} \mathrm{~W}$ językach zachodnich $\boldsymbol{w}$ transkrybuje się na ogół przez $s h$.

${ }^{14}$ E. JENNI, Lehrbuch der hebräischen Sprache des Alten Testaments, s. 32, oddaje samogłoski $\mathrm{z} \uparrow \mathrm{i}$, jako mater lectionis podobnie jak samogłoski długie bez nich: $\bar{a}, \bar{e}, \bar{e}, \bar{l}, \bar{o}, \bar{u}$. Transliteracja alfabetu hebrajskiego, s. 6 , oddaje ${ }_{-}-\operatorname{przez} \bar{a}(y)$. Można też spotkać zapis $\grave{e}$ dla -- . 


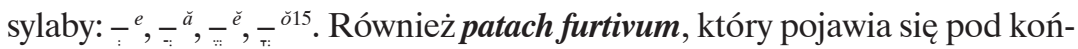
cową spółgłoską gardłową: ה ( musi mieć kropkę w środku, tzw. mappiq, jeśli ma być spółgłoską na końcu wyrazu), $\pi$, ע, gdy przed nią stoi długie $e$, $i, o$ lub $u$, piszemy w indeksie górnym, bo nie jest samodzielną samogłoską i nie tworzy sylaby: חᄁּ $r \hat{u}^{a} h$ (duch) ${ }^{16}$.

W wymowie nie słychać praktycznie, czy samogłoska jest krótka, czy długa, dlatego w transkrypcji używa się prostych liter: $a, e, o, i, u$. Wyjątek stanowią $s z^{e} w a$ proste i patach furtivum, które wymawia się rzeczywiście krótko, dlatego transkrybujemy je także w indeksie górnym: ${ }^{e},{ }^{a}$. Taki zapis jest chyba zrozumiały nawet dla nieznających hebrajskiego, że mianowicie chodzi o bardzo krótką samogłoskę.

Przy w i trzeba uważać na samogłoskę $\bar{o}$, bo czasem nie jest ona oznaczona osobną kropką, lecz „ukrywa się” w kropce spółgłoski. Pamiętając, że wyraz hebrajski musi zaczynać się od spółgłoski (wyjątkiem jest tylko początkowe $\hat{u}$, które stanowi jednak szczególną postać spójnika ? $w^{e}$ [i]), i że każda spółgłoska musi mieć swoją samogłoskę, łatwo sobie poradzić z tym

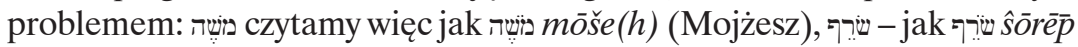

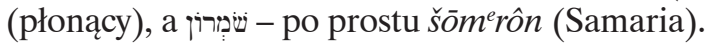

Matres lectionis mogą niekiedy przysparzać trudności. W wypadku ה sprawa jest bardzo jasna: na końcu wyrazu spółgłoska ta jest zawsze mater lectionis, dlatego w transliteracji będziemy ją stawiać wtedy w nawiasie, a w transkrypcji w ogóle jej nie uwzględnimy: תîn tôrā $(h)$, tora (pouczenie,

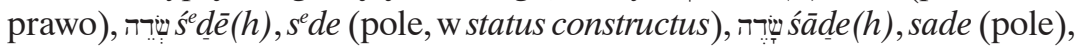

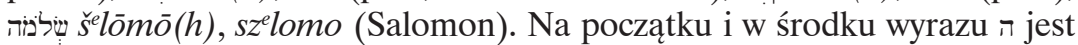

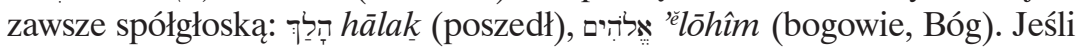

${ }^{15}$ Dokładnie tak transliteruje $s z^{e} w a$ J. WeIngreen, A Practical Grammar for Classical Hebrew, Second edition, Oxford 1959 (1967), s. 9-10. T. O. LAmbDin, Introduction to Biblical Hebrew, s. XXV, oddaje $\mathrm{s}^{e} w a$ proste przez odwrócone $e$ normalnej wielkości, natomiast J. W. L. RosŁon, Podręcznik języka hebrajskiego, s. 15, pisze odwrócone $e$ w indeksie górnym. Natomiast $s z^{e} w a$ złożone jest najczęściej oddawane przez $\breve{a}, \breve{e}, \breve{o}$ pisane normalnie. W indeksie górnym, ale przy pomocy innych nieco znaków, zaznaczają je A. KuśmireK (przekł. i opr.), Hebrajsko-polski Stary Testament. Ksiega Rodzaju, s. XV: ${ }^{a},{ }^{e},{ }^{o}$; W. Gesenius, E. Kautzsch, Hebräische Grammatik, Sieben und zwanzigste vielfach verbesserte und vermehrte Auflage, Leipzig 1902, s. 46. 49: ${ }^{a},{ }^{e}\left({ }^{\breve{e}}\right),{ }^{o} ;$ J. W. L. RosŁON, s. 12: ${ }^{a},{ }^{e},{ }^{o}$, i E. JENNI, Lehrbuch der hebräischen Sprache des Alten Testaments, s. 50-51: ${ }^{a},{ }^{a}, \stackrel{a}{ }$. Dla A. CARrozzInI, Grammatica della lingua ebraica, s. 10; G. Deiana, A. Spreafico, S. Bazyliński, Wprowadzenie do hebrajszczyzny biblijnej, s. 17, i J. W. L. RosŁon, s. 13-15, samogłoski zredukowane nie są sylabotwórcze, natomiast dla P. Joüon, Grammaire de l'hébreu biblique, s. 31; T. O. LAMBDIN, s. XVIII; E. JENNI, s. 50, i W. J. TYLoch, Gramatyka języka hebrajskiego, Warszawa 1980, s. 83, samogłoski zredukowane mogą tworzyć sylaby, chociaż sylaby takie nie są nigdy akcentowane i opierają się na następnej; niektórzy nazywają je półsylabami.

${ }^{16}$ Por. P. Joüon, Grammaire de l'hébreu biblique, s. 61; W. Gesenius, E. Kautzsch, Hebräische Grammatik, s. 39; A. CARRozzInI, Grammatica della lingua ebraica, s. 5; T. O. LAMBdin, 
na końcu wyrazu ma być spółgłoską, to otrzymuje wówczas mappiq i jest

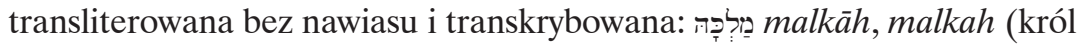
jej); gdyby $\mathrm{n}$ w tym przykładzie było mater lectionis, mielibyśmy zupełnie inny

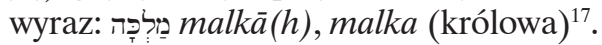

Łatwo również rozpoznać, kiedy ` jest mater lectionis. Zachodzi to wtedy, gdy nie ma samogłoski, ale tylko po $e, \bar{e}, i$ lub $\bar{a}$ (w pierwszym i ostatnim

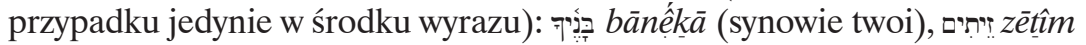

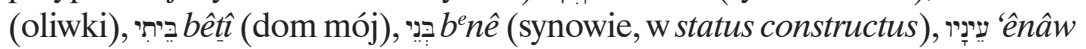
(oczy jego). Końcowy ' po $a, o, u$ jest zatem czytany: אִדר

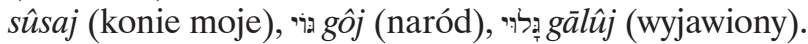

Najwięcej problemów jest $\mathrm{z}$, ponieważ i można rozumieć jako $\hat{o}, w \bar{o}$ lub $\bar{o} w$, a $\urcorner-$ jako $\hat{u}$ lub $w w$. Otóż ? oznacza $\hat{u}$, gdy nie jest opatrzony samogłoską; ma to miejsce zawsze na początku i na końcu wyrazu, a często

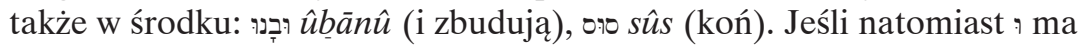
samogłoskę, oznacza wtedy podwojoną spółgłoskę $w$; ma to miejsce tylko w środku wyrazu: אִ אִ 'iwwélet (głupota), a nie 'iûélet. Znak i na końcu wyrazu oznacza zawsze samogłoskę: בִיתו bêtô (dom jego). Jeśli natomiast i znajdzie się w środku wyrazu, to trzeba go tak odczytać, żeby nie spotkały się bezpośrednio ze sobą spółgłoski czy samogłoski: טiv trzeba zatem czytać tôb (dobry), a nie tôw $\underline{b}$ czy twōb ; לִ - lōwe(h) (pożyczający) ${ }^{18}$, a nie lwōe(h)

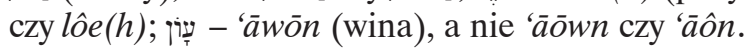

Niekiedy również $₫$ zachowuje się jak mater lectionis. Spółgłoska ta jest spoczywająca, gdy nie rozpoczyna sylaby, co praktycznie poznać po tym, że nie ma samogłoski. Nie zdarza się to nigdy na początku wyrazu. Dla większej dokładności będziemy umieszczać taki spoczywający $\mathbf{w}$ wawiasie:

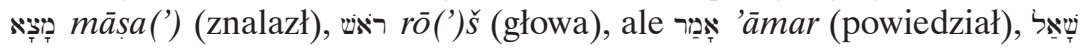
šă'al (zażądał), רָ rầ'

Introduction to Biblical Hebrew, s. XXI. XXVII; E. JENNI, Lehrbuch der hebräischen Sprache des Alten Testaments, s. 36; J. W. L. RosŁon, Podręcznik języka hebrajskiego, s. 11. Wielu oddaje tę samogłoskę przez normalne $a$.

${ }^{17}$ Por. Transliteracja alfabetu hebrajskiego, s. 6; P. JoüOn, Grammaire de l'hébreu biblique, s. 31. 36; A. CARrozzinI, Grammatica della lingua ebraica, s. 6. S. ŁACH, J. ŁACH (opr.), Księga Psalmów. Wstęp - przekład z oryginatu - komentarz - ekskursy, Poznań 1990, s. 36 (Pismo Święte Starego Testamentu 7, 2), oddają i bez mappiqa przez $h$ z łukiem u dołu, a A. TschIRschNiTz, K. WoJCIECHOwsKa, Gramatyka języka hebrajskiego w zarysie, Warszawa 1996, s. 44, przez ${ }^{h}$. Wielu nie zaznacza nieobecności mappiqa w końcowym $\pi$, oddając je przez $h$ bez nawiasu; por. np. T. O. LAMBdin, Introduction to Biblical Hebrew, s. XXV. Inni opuszczają zupełnie $h$; por. E. JENNI, Lehrbuch der hebräischen Sprache des Alten Testaments, s. 32, który pisze: $\bar{a}, \bar{e}, \bar{e}, \bar{o}$. J. W. L. RosŁon, Podręcznikjęzyka hebrajskiego, s. 19, transliteruje - - -przezâ, natomiast W. GESENIUs, E. KAUTzSCH, Hebräische Grammatik, s. 39, oddaje $\mathbf{- - p r z e z ~ e ̀ . ~ S p o t y k a m y ~ t e z ̇ ~ z a p i s ~} \hat{e}$ dla $\mathbf{-}-$.

${ }^{18}$ Samogłoska $\bar{o}$ w takich wypadkach znajduje się nad , a nie nad poprzednią spółgłoską.

${ }^{19}$ Autorzy raczej rzadko stawiają spoczywający « w nawiasie. Czynią to, choć nie do końca konsekwentnie, a czasem go zupełnie opuszczają, np. E. JENNI, Lehrbuch der hebräischen 
Również inne litery zbyteczne w danym wyrazie można transliterowaćw nawiasie, a w transkrypcji je opuszczać:

$S z^{e}$ wa złożone -, -, - - nie nastręcza trudności, bo jest zawsze translitero-

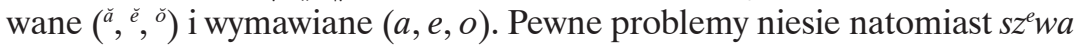
proste -, które może być ruchome (wtedy jest wymawiane jako krótkie $e$ ) oraz transliterowane i transkrybowane jako ${ }^{e}$, lub spoczywające (wtedy jest niewymawiane i pomijane $\mathrm{w}$ transliteracji i transkrypcji ${ }^{21}$. Problem polega na tym, kiedy $s z^{e} w a$ proste wymawiać, a kiedy nie. Zasady są następujące:

- sze wa wymawiamy na początku wyrazu: בִּרִ

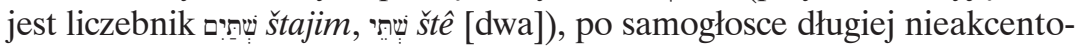

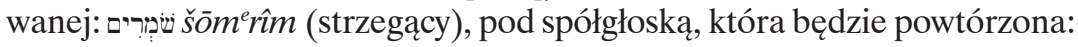
צִ sִillele (cienie, w status constructus), pod spółgłoską z dageszem, także na

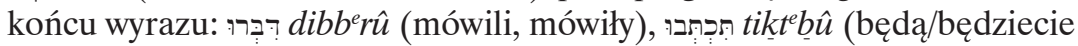

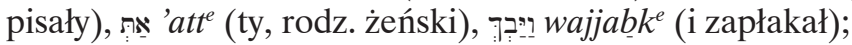

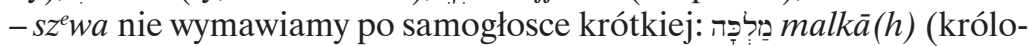

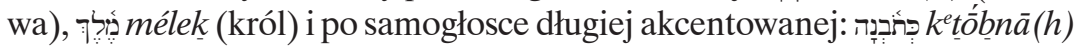

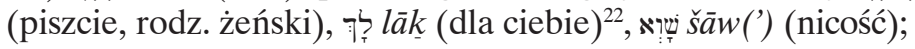

- jeśli dwa $s z^{e} w a$ proste występują obok siebie, to czytane jest tylko to

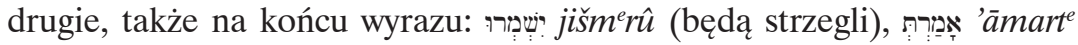
(powiedziałaś), $q \overline{o s ̌ t} t^{e}$ (prawda) ${ }^{23}$.

Nie uwzględniamy tzw. szewa pośredniego (medium) pomiędzy ruchomym a spoczywającym, które dawniej było wymawiane: מַּלְבי transliterujemy więc malkêe, nie malek̂e (królowie, w status constructus). Czynimy tylko wyjątek dla $s z^{e} w a$ znajdującego się pod spółgłoską, która powinna być podwojona. Czytamy je, a więc transliterujemy i transkrybujemy także. Dotyczy to głównie spółgłosek

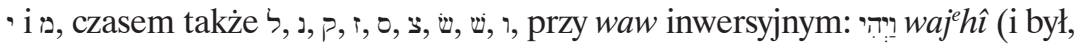

Sprache des Alten Testaments, s. 31. 33, i T. O. LAmbdin, Introduction to Biblical Hebrew, s. XXIV. Samogłoskę $\bar{o}$ przed takim $\aleph$ umieszcza się nad jego prawym końcem górnym (ראש), a nie nad spółgłoską, do której należy (ראש)); por. P. JoüON, T. MURAOKA, A Grammar of Biblical Hebrew, s. 35.

${ }^{20}$ Por. Transliteracja alfabetu hebrajskiego, s. 6.

${ }^{21}$ A. KuŚMIREK (przekł. i opr.), Hebrajsko-polski Stary Testament. Księga Rodzaju, zaznacza każde $s z^{e} w a$, czego raczej się nie spotyka w literaturze biblijnej. Odpowiadałoby to wprawdzie ścisłej transliteracji, w której chodzi o oddanie każdego znaku danego alfabetu, ale w wypadku języków starożytnych nie można tego robić w sposób mechaniczny; por. Transliteracja alfabetu hebrajskiego, s. 9. Pamiętać trzeba, że szewa znaczy po prostu „nic”, „brak” i pierwotnie zaznaczało właśnie brak samogłoski; por. J. W. L. RosŁon, Podręcznik języka hebrajskiego, s. 15.

${ }^{22}$ Końcowy $\rceil k$ otrzymuje zawsze $s z^{e} w a$, jeśli nie ma innej samogłoski, dla odróżnienia go od końcowego $\uparrow$.

${ }^{23}$ W kwestii $s z^{e} w a$ na końcu wyrazu istnieją trzy stanowiska: 1) jest ono zawsze spoczywające; por. T. O. LAmbdin, Introduction to Biblical Hebrew, s. XXVI-XXVII; E. JENNI; Lehrbuch der hebräischen Sprache des Alten Testaments, s. 36-37; J. W. L. RosŁon, Podręcznik języka hebrajskiego, s. 16; W. J. TYLOCH, Gramatyka języka hebrajskiego, s. 57-58; J. WeInGREEN, 


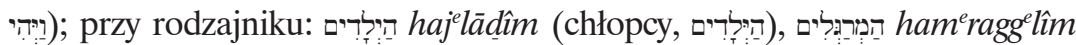

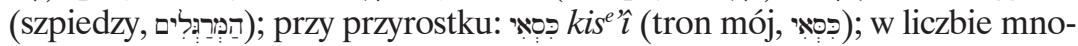

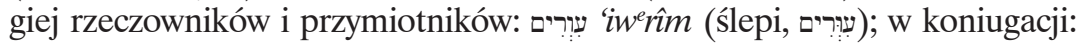

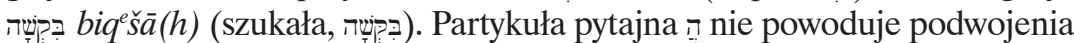
pierwszej spółgłoski wyrazu, do którego przyłącza się jako przedrostek, dlatego הַילדרים będziemy transliterować hajlādîm (czy chłopcy?) ${ }^{24}$.

Dwuznaczny jest znak -, który może być $\bar{a}$ lub $o$. Zasada podstawowa mówi, że znak ten oznacza $o$ w sylabie zamkniętej (zakończonej spółgłoską), nieakcentowanej, bo w takiej sylabie musi być samogłoska krótka: jấqom (i powstał). Ma to zawsze miejsce przed spółgłoską z dageszem forte: רִָ ronnî (ciesz się, rodz. żeński) i w sylabie zamkniętej przed maqqefem (łącznikiem oddawanym w transliteracji i transkrypcji), bo wyraz przed maqqefem

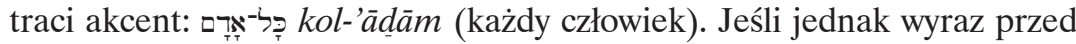
maqqefem kończy się na $\aleph_{\text {lub }}$, znak ten oznacza $\bar{a}$, bo spółgłoski te są tu

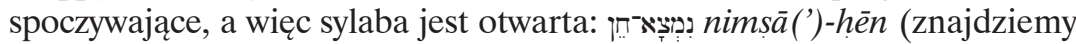

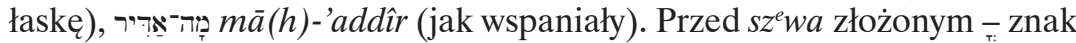

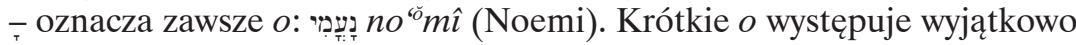

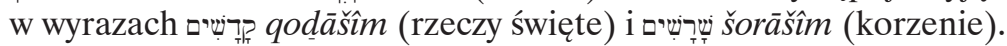

W sytuacjach niepewnych pomoże nam meteg (wędzidło), mała pionowa kreseczka stawiana pod spółgłoską z lewej strony samogłoski ${ }_{i \pi}^{25}$, której się nie transliteruje. Między swoimi różnymi funkcjami (np. drugorzędnego

A Practical Grammar for Classical Hebrew, s. 9; 2) niekiedy jest ruchome zgodnie z podanymi wyżej regułami; por. A. CARrozzinI, Grammatica della lingua ebraica, s. 4-5; G. DeiAnA, A. Spreafico, S. Bazyliński, Wprowadzenie do hebrajszczyzny biblijnej, s. 13-14; P. Joüon, T. Muraoka, A Grammar of Biblical Hebrew, s. 53; P. Joüon, Grammaire de l'hébreu biblique, s. 30-31; ten ostatni uważa, że należy czytać $s z^{e} w a$ nie tylko w s 'att' (ty, rodz. żeński) czy qātalt (zabiłaś), ale tym bardziej w jest spoczywające, ale w podanych wyżej wypadkach ma wiele z ruchomego; por. W. GESEnIUs, E. KaUtzsch, Hebräische Grammatik, s. 50-51; A. Tschirschnitz, K. WoJciechowskA, Gramatyka języka hebrajskiego w zarysie, s. 33-34. Szewa wymawiane pod końcową spółgłoską jest zatem szczególnym przypadkiem, według zgodnej opinii pozostałością po końcówce - $\hat{\imath}$ lub -e(h). Nasze stanowisko pragnie uwzględnić wypadki $s z^{e} w a$ ruchomego na końcu wyrazu i stosuje do niego te same zasady, co do $s z^{e} w a$ w początkowej czy środkowej sylabie.

${ }^{24} S z^{e}$ wa medium występuje po krótkiej samogłosce, ale nie zamyka całkowicie sylaby, co widać po tym, że spółgłoski z grupy BeGaDKeFaT nie otrzymują dagesza: Poje ono, jak już wspomniano, pod spółgłoską, która powinna być podwojona, a także w status constructus rzeczowników segolowych (tylko w liczbie mnogiej) oraz rzeczowników o dwóch samogłoskach pierwotnie krótkich typu dābar i $s^{e} d \bar{a} q \bar{a}(h)$, przy końcówce - $\bar{a}(h)$ oznaczającej kierunek, w trybie rozkazującym, w bezokoliczniku z przyrostkami, po przyimkach $b^{e}, k^{e} \mathrm{i} l^{e}$, przed przyrostkami -kem, -ken i często -kāa; por. P. Joüon, Grammaire de l'hébreu biblique, s. 31-33; W. J. Tyloch, Gramatyka języka hebrajskiego, s. 58-59. Sz wa pośrednie dzisiaj się pomija; por. np. G. Deiana, A. Spreafico, S. BAZYliński, Wprowadzenie do hebrajszczyzny biblijnej, s. 14; T. O. LAmBdin, Introduction to Biblical Hebrew, s. XXVI. Ten ostatni autor czyni to konsekwentnie, czytając np. zawsze wajhi. 
akcentu w wyrazie) znak ten wskazuje przede wszystkim na jakąś niere-

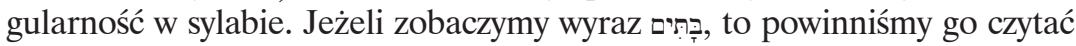
bottîm. Dodany meteg בתָּ mówi nam, że wbrew zasadzie, iż w sylabie zamkniętej nieakcentowanej powinna być samogłoska krótka, należy czytać bāttîm (domy). Gdy widzimy wyraz אָּלָָ, to normalnie powinniśmy czytać go ’oklā $(h)$ (jedzenie), ponieważ lektura 'âk $k^{e} l \bar{a}(h)$ (zjadła) kłóci się z zasadą, że $\bar{a}$ i $\bar{e} \mathrm{w}$ drugiej sylabie od akcentowanej, a $\bar{e} \mathrm{w}$ pierwszej sylabie od akcen-

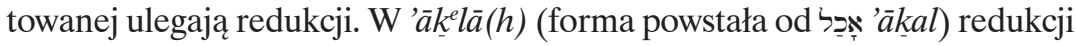
do $s z^{e} w a$ uległa krótka samogłoska środkowa $a$. W takim wypadku dodawany jest często meteg: nie ma oddzielnego znaku. Wtedy zwykle stawia się również meteg: יראי jir'û

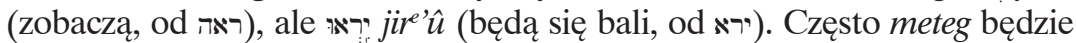
wskazywał, żeby czytać $s z^{e} w a$ mimo poprzedzającej samogłoski krótkiej: הַ: hal lî̀ (chwalcie, rodz. męski).

\section{Objaśnienia innych znaków}

O niektórych znakach już wspomnieliśmy (o dageszu przy spółgłoskach, a o mappiqu, maqqefie i metegu przy samogłoskach), zajmijmy się więc pozostałymi.

Tekst masorecki jest zaopatrzony w akcenty. Jest to system ponad trzydziestu znaków, których zasadniczo nie oddaje się w transliteracji i w transkrypcji. W pierwszym rzędzie akcenty mają funkcję dynamiczną, to znaczy pokazują, która sylaba ma być wymówiona mocniej. Najczęściej bywa nią sylaba ostatnia, rzadziej przedostatnia. Dobrze jest zaznaczać akcent w tym drugim przypadku dla poprawności wymowy, jak to czynimy konsekwentnie w tym artykule: מֶל

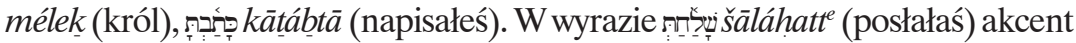
nie pada na trzecią sylabę od końca, bo $s z^{e} w a$ nie tworzy pełnej sylaby ${ }^{27}$. Niekiedy akcent pozwala odczytać znaczenie słowa: wali, zbudowały). Akcenty pełnią też rolę naszej interpunkcji. Najważniejszy z nich to silluq -, który stoi w ostatnim wyrazie wersetu i wraz z sof pasuq (:) odpowiada naszej kropce. Zazwyczaj stawia się ją w transliteracji i transkrypcji:

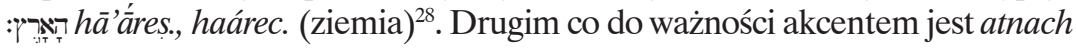

${ }^{25}$ Biblia Hebraica Stuttgartensia, ed. K. Elliger, W. Rudolph, editio quinta emendata, Stuttgart 1997, stawia czasem meteg i z prawej strony samogłoski -; por. np. Rdz 1, 7: waj'hî (i był).

${ }^{26}$ W Biblia Hebraica Stuttgartensia, ed. K. Elliger, W. RudolPH, nie występuje on zawsze;

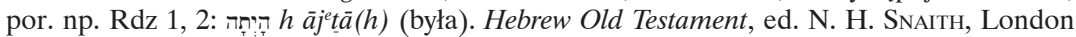
1958, zaznacza meteg konsekwentnie.

${ }^{27}$ P. Joüon, Grammaire de l'hébreu biblique, s. 15. 31, transliteruje ten wyraz šăláhate, ponieważ forma ta wzięła się z z ש̌ šălahte. 
-, stojący w wyrazie kończącym pierwszą połowę wersetu, który odpowiada naszemu średnikowi lub przecinkowi: אליה 'oèhîm, (bogowie, Bóg). Akcent ten nie zawsze dobrze koresponduje $\mathrm{z}$ naszą interpunkcją, dlatego lepiej go nie zaznaczać w transliteracji i transkrypcji ${ }^{29}$.

W dawniejszych publikacjach można było spotkać rafe, kreskę nad spółgłoską, która nie posiada dagesza forte lub lene (ten ostatni dotyczy tylko grupy $B e G a D$ $\mathrm{KeFaT}$ ), i nad $\mathrm{a}$ bezmappiqa. Znak ten może się też pojawić nad spoczywającymi

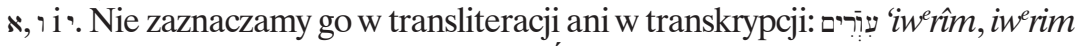
(ślepi), 醇 jāpe(h), jafe (piękny),

Liczby hebrajskie oznaczane przy pomocy liter oddaje się cyframi arabskimi, podstawiając odpowiednią liczbę pod daną literę i sumując je, jeśli ostateczną

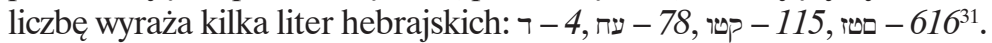

Wśród korekt masoretów znajdują się poprawki stałe (qeêe perpetuum), polegające na tym, że wyraz opatrzono samogłoskami, które pokazują, jak należy go czytać. Wśród nich mamy w pierwszym rzędzie tetragram יהוה $J H W H$, czyli imię BogaJahwe(h), którego żydzi nie wymawiają, lecz zastępują

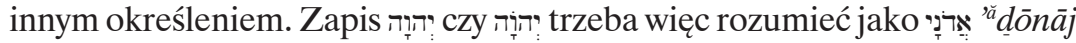

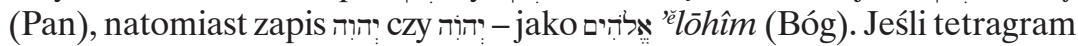
poprzedzony jest przyimkiem $¥ b^{e}(\mathrm{w}), k^{e}$ (jak), ל? $l^{e}$ (dla) lub spójnikiem

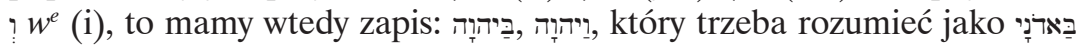

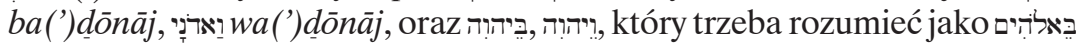

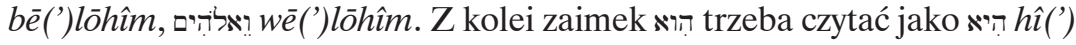

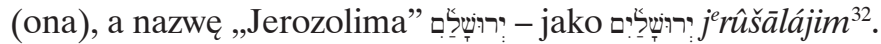

Niektórzy oddzielają łącznikiem przedrostki (rodzajnik, przyimek, spój-

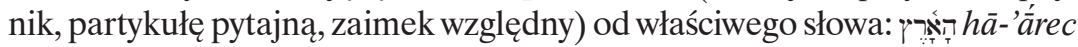

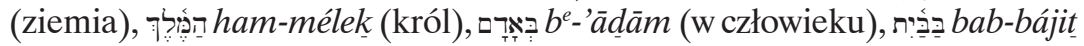

${ }^{28}$ Silluq wygląda dokładnie jak meteg, jednak nigdy nie znajduje się w sylabie akcentowanej; por. G. Deiana, A. SPreafico, S. Bazyliński, Wprowadzenie do hebrajszczyzny biblijnej, s. 21.

${ }^{29} \mathrm{~W}$ naszym przykładzie wziętym z Rdz 1,1 nie można w polskim tłumaczeniu postawić przecinka po „Bóg”: „Na początku stworzył Bóg, niebiosa i ziemię”.

${ }^{30}$ Por. P. Joüon, T. Muraoka, A Grammar of Biblical Hebrew, s. 57-58; A. CArrozzini, Grammatica della lingua ebraica, s. 9.

${ }^{31}$ Ostatnią liczbę 616 można też oddać w inny sposób, nie korzystając z form końcowych

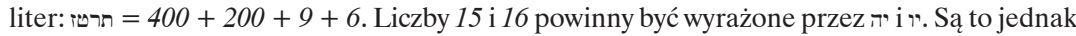
skróty imienia Jahwe(h), dlatego zaznacza się je odwracając kolejność tych liter: הי i lub zestawiając inne litery: טv ט $\mathrm{i}$. Tysiące są oznaczane kolejnymi literami alfabetu zaopatrzonymi w dwie kropki u góry: $\aleph, ~ \beth$ itd. Użycie liter na oznaczanie liczb jest potwierdzone od II w. przed Chr.; por. P. JoüOn, T. MuraOKA, A Grammar of Biblical Hebrew, s. 22-23; Transliteracja alfabetu hebrajskiego, s. 3-4; J. W. L. RosŁon, Podręcznik języka hebrajskiego, s. 135; E. JENNI, Lehrbuch der hebräischen Sprache des Alten Testaments, s. 18. Biblia Hebraica Stuttgartensia, ed. K. Elliger, W. Rudolph, stawia kropkę nad literami oznaczającymi liczby: עטا, עז ד.

${ }^{32}$ Por. A. Carrozzini, Grammatica della lingua ebraica, s. 19-20. 


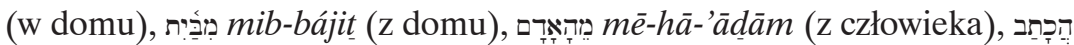

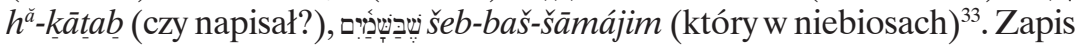
ten myli się jednak z maqqefem.

Litery i liczby w transliteracji i w transkrypcji pisze się kursywą.

\section{Przykłady}

W zależności od potrzeb i możliwości typograficznych można stosować transliterację pełną lub uproszczoną albo uciec się do transkrypcji. Ważne jest, aby stosowaćje konsekwentnie w danej pracy. Zobaczmy proponowany system transliteracji i transkrypcji na przykładach Rdz 1, 1-2 i Ps 119, 34. $36^{34}$ :

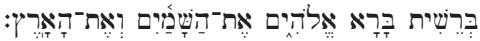

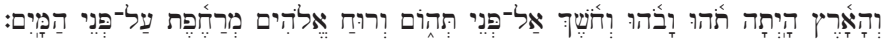

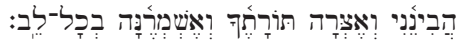

Transliteracja:

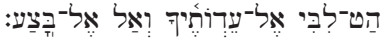

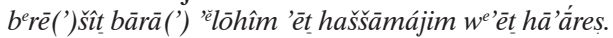

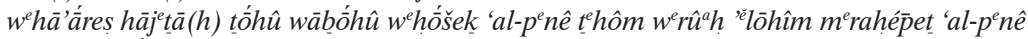
hammá̀jim.

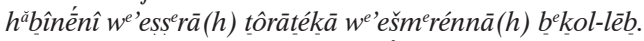

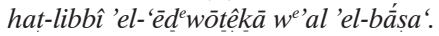

Transkrypcja:

$b^{e}$ reszit bara elohim et haszszamájim weet haárec.

wehaárec hajeta tóhu wawóhu wechószech al-pene tehom weruach elohim merachéfet al-pene hammájim.

hawinéni weeccera toratécha weeszmérénna wechol-lew.

hat-libbi el-edewotécha weal el-báca.

Jeśli w transliteracji zrezygnujemy z zaznaczania akcentu dynamicznego i braku dagesza lene w grupie $B e G a D K e F a T$ oraz opuścimy nawiasy przy « i i, otrzymamy wówczas zapis:

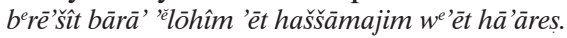

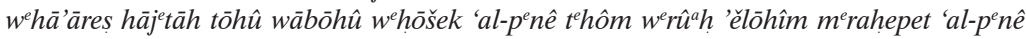
hammājim.

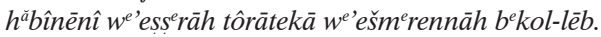

hat-libbî 'el-'éd'wōtêk $\bar{a} w^{e}$ 'al 'el-bāsạ .

Niekiedy upraszcza się w transliteracji także zapis samogłosek:

bere'sit bara' 'elohim 'et haššamajim we'et ha'ares.

weha'areș hajetah tohu wabohu wehošek 'al-pene tehom weruah 'elohim merahepet 'alpene hammajim.

${ }^{33}$ Por. Transliteracja alfabetu hebrajskiego, s. 6-7.

${ }^{34}$ Według Biblia Hebraica Stuttgartensia, ed. K. Elliger, W. Rudolph, z pominięciem większości akcentów. 
habineni we'esșerah torateka we'ešmerennah bekol-leb.

hat-libbi 'el-'edewoteka we'al 'el-basa'.

Można wreszcie zapisywać same tylko spółgłoski; wówczas zaznacza się również te, które występują jako matres lectionis ${ }^{35}$ :

br'šjt br' 'Thjm 't hšmjm w't h'rș.

wh'rs hjth thw wbhw whšk 'l-pnj thwm wrwh 'lhjm mrhpt 'l-pnj hmjm.

hbjnnj w'șrh twrtk w'šmrnh bkl-lb.

$h t-l b j$ 'l-'dwtjk w'l 'l-bss'.

Również w transkrypcji można zrezygnować z zaznaczania akcentu oraz pisania $s z^{e} w a$ i patach furtivum $\mathrm{w}$ indeksie górnym; wtedy zapis będzie jeszcze prostszy, ale najmniej precyzyjny:

bereszit bara elohim et haszszamajim weet haarec.

wehaarec hajeta tohu wawohu wechoszech al-pene tehom weruach elohim merachefet al-pene hammajim.

hawineni weeccera toratecha weeszmerenna wechol-lew.

hat-libbi el-edewotecha weal el-baca.

Kraków

KS. STANISEAW WRONKA

\section{Riassunto}

\section{La traslitterazione e la trascrizione dell'alfabeto ebraico}

L'autore dell'articolo richiama prima l'attenzione sulla differenza, di solito trascurata, fra la traslitterazione e la trascrizione. Ambedue rendono le lettere di un alfabeto con le lettere di un altro alfabeto, ma la prima concerne le stesse lettere, mentre la seconda - la loro pronuncia. In seguito propone ed esplica un sistema, fra tanti possibili e usati, della traslitterazione e della trascrizione, presentando sugli esempi come esso funziona. Lo scopo dell'articolo è offrire un punto di riferimento a chi deve traslitterare o trascrivere un testo ebraico, ma anche provocare una discussione per arrivare eventualmente ad un sistema unico della traslitterazione e della trascrizione, il che faciliterebbe la lettura dei nostri testi biblici e teologici.

${ }^{35}$ Por. np. L. Alonso Schökel, J. Vilchez Lindez, A. Pinto, Sapienciales. I Proverbios, Madrid 1984 (Neuva Biblia Española. Comentario teológico y Literario). 